\title{
Significance of Over-Mature and Decaying Trees for Carbon Stocks in a Central European Natural Spruce Forest
}

\author{
Mascha Jacob, ${ }^{1 *}$ Claudia Bade, ${ }^{1}$ Héctor Calvete, ${ }^{1,2}$ Sebastian Dittrich, ${ }^{1}$ \\ Christoph Leuschner, ${ }^{1}$ and Markus Hauck ${ }^{1}$
}

\begin{abstract}
${ }^{1}$ Plant Ecology, Albrecht von Haller Institute for Plant Sciences, University of Göttingen, Untere Karspüle 2, 37073 Göttingen, Germany; ${ }^{2}$ Present address: Ecotoxicity of Atmospheric Pollutants Technology, Research Center for Energy, Environment and Technology (CIEMAT), Avda. Complutense 40, 28040 Madrid, Spain
\end{abstract}

\begin{abstract}
Old-growth forests are important stores for carbon as they may accumulate $\mathrm{C}$ for centuries. The alteration of biomass and soil carbon pools across the development stages of a forest dynamics cycle has rarely been quantified. We studied the above- and belowground $\mathrm{C}$ stocks in the five forest development stages (regeneration to decay stage) of a montane spruce (Picea abies) forest of the northern German Harz Mountains, one of Central Europe's few forests where the natural forest dynamics have not been disturbed by man for several centuries. The over-mature and decay stages had the largest total (up to $480 \mathrm{Mg} \mathrm{C} \mathrm{ha}^{-1}$ ) and aboveground biomass carbon pools $\left(200 \mathrm{Mg} \mathrm{C} \mathrm{ha}^{-1}\right)$ with biomass $\mathrm{C}$ stored in dead wood in the decay stage. The
\end{abstract}

\section{INTRODUCTION}

The earth's forests with an extension of approximately 42 million $\mathrm{km}^{2}$ store about $45 \%$ of the global terrestrial carbon (Bonan 2008). Recent studies

Received 31 March 2012; accepted 13 October 2012; published online 4 December 2012

Author Contributions: $\mathrm{MH}, \mathrm{CL}$, and $\mathrm{MJ}$ conceived of and designed the study; $\mathrm{CB}, \mathrm{HC}, \mathrm{SD}$, and $\mathrm{MJ}$ performed the research and analyzed the data; $\mathrm{MH}, \mathrm{CL}$, and MJ wrote the paper.

*Corresponding author; e-mail: mjacob@gwdg.de soil C pool (220-275 $\left.\mathrm{Mg} \mathrm{C} \mathrm{ha}^{-1}, 0-60 \mathrm{~cm}\right)$ was two to three times larger than in temperate lowland spruce forests and remained invariant across the forest dynamics cycle. On the landscape level, taking into account the frequency of the five forest development stages, the total carbon pool was approximately $420 \mathrm{MgC} \mathrm{ha}^{-1}$. The results evidence the high significance of over-mature and decaying stages of temperate mountain forests not only for conserving specialized forest organisms but also for their large carbon storage potential.

Key words: climate change; boreal forest; forest biomass; growth dynamics; primary forest; coarse woody debris; Picea abies; Harz Mountains. 
Dolman and others (2010) who provided some evidence that old-growth forests may take up more carbon than formerly expected.

Beside forest age, forest management (including deforestation) has a large influence on the global carbon cycle with deforestation accounting for approximately $18 \%$ of the global $\mathrm{CO}_{2}$ net release to the atmosphere (IPCC 2007). In forests intensively exploited for timber, both the biomass and soil C stocks generally decrease with increasing forest management intensity (Schulze and others 1999; Yanai and others 2003). This aspect is highly relevant for Europe's forests which have been subjected to a variety of management impacts during the past centuries or sometimes even millennia (Ciais and others 2008; Ellenberg and Leuschner 2010). These anthropogenic disturbances included not only timber harvest, but also litter raking, fuel wood collection, and wood pasture. A likely consequence are unbalanced soil carbon stocks, reduced soil fertility, and often decreased wood biomass stocks in many contemporary stands as compared to old-growth forests (Glatzel 1999).

Unmanaged old-growth forests have a more diverse stand structure and harbor more deadwood than managed forests (Chatterjee and others 2009). Natural stand dynamics proceed from a phase with abundant offspring to a stage with rapid height growth and canopy expansion to late stages with over-mature and finally decaying trees. Over-mature trees and deadwood with large diameters are usually absent from managed temperate forests. Their conservation may reduce timber yield, but these old trees are of high value for biodiversity conservation by providing habitats for numerous specialized organisms, including hole-nesting birds, bats, xylophagous insects, fungi, lichens, and bryophytes, that are rare or absent from the earlier development stages (Schiegg 2000; Ódor and others 2006; Hilmo and others 2009).

The objective of this study was to examine the significance of over-mature and decaying forest patches for the carbon storage in biomass (live and dead) and soil of a coniferous mountain forest ecosystem. We conducted a case study in a montane spruce forest ecosystem on Mt. Brocken, Germany, which was spared from intense forest management for centuries and thus represents one of central Europe's rare examples of a forest with natural stand dynamics and all different development stages being present in a mosaic of forest patches (Stöcker 1997). We used this study object to test the hypotheses that stages with predominantly over-mature and decaying trees are characterized by (1) higher aboveground and (2) higher soil carbon stocks, assuming a positive effect of an increasing amount of deadwood and of long periods without forest management on the carbon transfer from biomass to the soil.

\section{MethoDS}

\section{Study Area and Sample Plot Selection}

The study was conducted on the eastern slope of Mt. Brocken, the highest peak of the Harz Mountains (1142 m a.s.l.) in northern Germany, at 900$1,000 \mathrm{~m}$ a.s.l. $\left(51^{\circ} 47^{\prime} \mathrm{N}, 10^{\circ} 38^{\prime} \mathrm{E}\right)$ in an old-growth spruce forest (P. abies (L.) H. Karst.) of 300 ha size. This forest stand was part of a protected hunting ground for deer, bears, wolves, and lynxes of the nobility and clergy since the early Middle Ages (ca. 800-1,500 AD, Schade 1926), and logging and forest pasture were prohibited (Jacobs 1871, 1878). Because of its restricted accessibility, the forest also has never been exploited for charcoal production during the long-lasting medieval mining period in the Harz Mountains (Kortzfleisch 2008). The oldest spruce trees in the forest are over 280-years-old (Hauck and others 2012a). The climate of Mt. Brocken is characterized by an annual precipitation of $1,600 \mathrm{~mm}$ (including $192 \mathrm{~mm}$ of snow), an annual mean temperature of $2.9^{\circ} \mathrm{C}$ (1961-1990), and 306 fog days per year (Glässer 1994). Parent rock material is granite; soils are Stagnic Cambisols and, more locally, Leptic Cambisols, and Histic Planosols. The typical humus form is mould.

The studied forest includes the full spectrum of development stages in a forest dynamics cycle. Five structurally defined development stages were distinguished following Stöcker (1997) (see Table 1). In each stage, five plots of $10 \mathrm{~m} \times 10 \mathrm{~m}$ were established. Due to the limited size of the oldgrowth stand, it was not possible to select the sample plots with a completely randomized design. However, the plots of a given development stage were more or less evenly spread over the forest area to avoid clumping of replicate plots in certain sections of the forest.

For extrapolating to the landscape level, we quantified the frequency of the five development stages in the whole study area of 300 ha. We chose four transects following the 925, 950, 975, and $1,000 \mathrm{~m}$ contour lines and assigned the forest at intervals of $20 \mathrm{~m}$ distance to the five development stages defined in Table 1. Patches showing within a $10-\mathrm{m}$ radius of the sample point the structural characteristics of two development stages were assigned by $50 \%$ to these two stages (this approach was necessary at $5 \%$ of the sample points). Bogs and forested scree fields were excluded from this 
calculation. The percental frequency values of the five stages were averaged over the four transects and extrapolated to the entire forest.

\section{Determination of Aboveground Biomass and Carbon Stocks}

The height of all trees with a diameter at breast height (dbh) greater than $7 \mathrm{~cm}$ was measured with a Vertex IV sonic clinometer and T3 transponder (Haglöf, Långsele, Sweden). The dbh was recorded with diameter measurement tapes at a resolution of $0.5 \mathrm{~mm}$. The height and diameter above buttresses (dab) of all spruce seedlings and saplings ( $\mathrm{dbh}<$ $7 \mathrm{~cm}$ ) were measured with a folding rule and a caliper. Furthermore, the length and diameter of the standing deadwood and the coarse woody debris with a minimum diameter greater than $2 \mathrm{~cm}$ were measured.

Species-specific allometric biomass equations established in mountain spruce forests of Bohemia (Czech Republic) (Cerný 1990) were used to estimate the total aboveground biomass of all living trees with a dbh greater than $7 \mathrm{~cm}$. Aboveground tree biomass $\left(B_{\mathrm{A}}\right.$, in $\left.\mathrm{kg}\right)$ was obtained from the expression

$$
B_{\mathrm{A}}=0.11975 \times\left(D^{2} \times H\right)^{0.81336}
$$

where $D$ is the diameter at breast height including bark (in $\mathrm{cm}$ ) and $H$ is the tree height (in m). The equation was established at trees in three 57-, 78and 106-year-old even-aged spruce stands at elevations of 540-630 $\mathrm{m}$ a.s.l. growing under comparable climatic and edaphic conditions as exist at our study site. Nevertheless, we are aware that published allometric equations generally face limitations when transferred to other sites, introducing possible errors in the calculated aboveground biomass figures (Rock 2007). Consequently, we discuss the biomass data with care. The seedling biomass $\left(B_{\mathrm{S}}\right.$, in $\mathrm{kg}$ ) was estimated after Chen (1997) with the equation

$$
B_{\mathrm{S}}=a+b H+c D
$$

with $a=-2.726, b=0.120$, and $c=0.658$. A carbon concentration of $0.504 \mathrm{~kg}_{\mathrm{C}} \mathrm{kg}_{\text {wood }}^{-1}$ was assumed for calculating the amount of stored carbon from the biomass estimates (Mund and others 2006). All biomass data refer to dry weight determined at $105^{\circ} \mathrm{C}$.

A decay class was assigned to every piece of coarse woody debris following Holeksa (2001) as defined in Table 2. Eight decay classes of logs and snags with a minimum diameter greater than $2 \mathrm{~cm}$ 


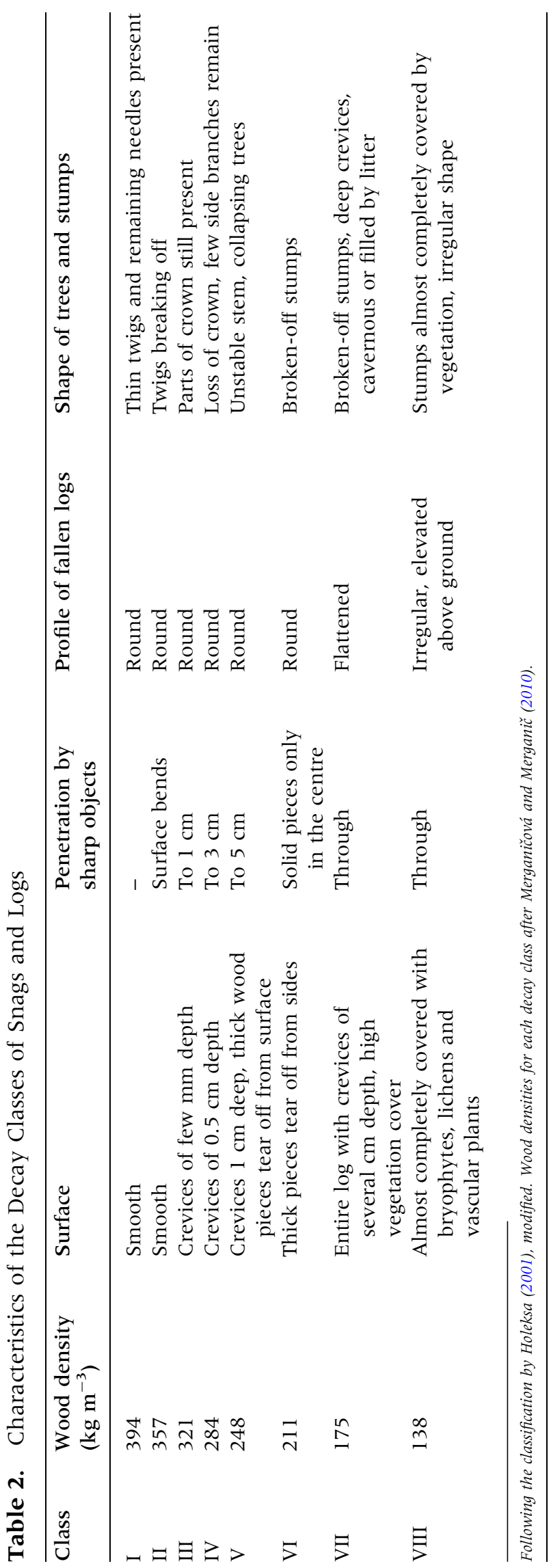

and length greater than $1 \mathrm{~m}$ were distinguished. The deadwood volume $\left(V\right.$, in $\left.\mathrm{m}^{2}\right)$ was obtained with the equation $\mathrm{V}=\pi r^{2} l$, where $r$ is the radius, and $l$ is the length $(\mathrm{cm})$. The volume of a few almost square-shaped tree stumps was calculated assuming the shape of a cuboid. We used the wood density in these eight decay classes as measured by Merganičová and Merganič (2010) and a carbon concentration of $0.504 \mathrm{~kg}_{\mathrm{C}} \mathrm{kg}_{\text {wood }}^{-1}$ (Mund and others 2006) to obtain the biomass and carbon stocks of all deadwood objects.

\section{Soil Sampling and Chemical Analyses}

Soil was sampled from four depths (0-10, 10-20, $20-40,40-60 \mathrm{~cm})$ in a soil profile in the center of each plot ( 25 plots in total). The litter layer was removed before sampling. At 40-60 $\mathrm{cm}$ depth, we could take samples only from a few plots owing to high stone content; these subsoil values, therefore, are discussed with care. Three samples per layer were taken with steel cylinders $\left(100 \mathrm{~cm}^{3}\right)$ for the analysis of $\mathrm{C}$ and $\mathrm{N}$ concentrations and saltextractable cation concentrations on a volume basis. Bulk density and water content of the cylinder samples were calculated after measuring fresh and dry weight $\left(105^{\circ} \mathrm{C}, 48 \mathrm{~h}\right)$. The stone content was obtained for each soil depth from volumetric and gravimetric measurements (steel cylinder samples), but was only visually assessed in the field in the subsoil. The carbon content was calculated for each soil layer from the measured $\mathrm{C}$ concentration, soil bulk density, and the stone content.

The $\mathrm{pH}$ was measured in suspensions of fresh soil samples in $\mathrm{H}_{2} \mathrm{O}$ or $1 \mathrm{~N} \mathrm{KCl}$ after $24 \mathrm{~h}$ with a MP $120 \mathrm{pH}$ meter and an InLab 413 electrode (MettlerToledo, Greifensee, Switzerland). For calculating base saturation, the concentrations of $\mathrm{K}, \mathrm{Na}, \mathrm{Mg}$, $\mathrm{Ca}, \mathrm{Al}, \mathrm{Fe}$, and $\mathrm{Mn}$ in $5 \mathrm{~g}$ of fresh soil extracted with $\mathrm{BaCl}_{2}(100 \mathrm{ml}, 2 \mathrm{~N})$ were measured with ICPOES (Optima 5300 DV, Perkin Elmer, Waltham, Massachusetts, USA). Dry soil samples $\left(70^{\circ} \mathrm{C}, 48 \mathrm{~h}\right)$ were pulverized with a disc mill and the total concentrations of $\mathrm{C}$ and $\mathrm{N}$ were measured with a $\mathrm{CN}$ analyzer (Vario EL III, Elementar Analysensysteme, Hanau, Germany).

\section{Statistical Analyses}

Arithmetic means \pm standard errors are presented throughout the paper. Significant differences of residuals of a one-way analysis of variance (ANOVA) for stand structure parameters, biomasses, and carbon stocks were tested for the five development stages. Pairwise comparisons between the different 
stages were made with Student's $t$ test. All data of model residuals were tested for normal distribution with the Shapiro-Wilk test and for homogeneity of variances with the Levene test. The carbon stocks in the different soil layers, which were not normally distributed, were tested with the KruskalWallis test. All statistical tests were done with $\mathrm{R}$ 2.14.1 (R Development Core Team, Vienna, Austria) software at a significance level of $P \leq 0.05$.

\section{RESUlts}

\section{Aboveground Biomass and Carbon Stocks}

The highest number of living trees exceeding a dbh of $7 \mathrm{~cm}$ was found in the initial stage (B), although standing deadwood was scarce (Table 3 ). Standing deadwood was even scarcer in the climax stage $(C)$, but started to increase in the over-mature stage (D) to a maximum in the decay stage (E) with a mean value of 460 dead stems ha $\mathrm{ha}^{-1}$ and a standing deadwood mass of $390 \mathrm{Mg} \mathrm{ha}^{-1}$ (Tables 3,4). The density of standing dead trees was only reduced to a small extent from the decay stage (E) to the regeneration stage (A) of the next forest generation (Table 3). However, because the height of the snags was strongly declining from stage $\mathrm{E}$ to $\mathrm{A}$, the standing deadwood biomass was strongly reduced (Table 4). Lying trunks and other lying coarse woody debris were more evenly distributed over the stages; their biomass pool ranged from $15 \mathrm{Mg} \mathrm{ha}^{-1}$ in the decay stage (E) to $41 \mathrm{Mg} \mathrm{ha}^{-1}$ in the over-mature stage (D) (Table 4).

The total aboveground carbon stocks, calculated as the sum the carbon stocks of living trees with a dbh greater than $7 \mathrm{~cm}$, tree seedlings and saplings, and the standing and lying deadwood, increased with proceeding stand development. The lowest carbon stocks were found in the regeneration (A) and initial (B) stages with significantly smaller biomass stocks and biomass carbon pools than in the over-mature (D) and decay (E) stages, where the aboveground biomass reached approximately $400 \mathrm{Mg} \mathrm{ha}^{-1}$ and the aboveground carbon stock was about $200 \mathrm{Mg} \mathrm{C} \mathrm{ha}^{-1}$ (Figure 1). The contribution of deadwood to the total biomass carbon pool was almost $100 \%$ in the regeneration (A) and decay (E) stages, and decreased to $6 \%$ in the climax stage (C) (Table 4). In over-mature (D) forest patches, $20 \%$ of the aboveground carbon was stored in deadwood with most of it located in the standing deadwood. The contribution of lying deadwood to the aboveground carbon stock was highest in the regeneration (A) and initial (B) stages.

Table 3. Stand Structure and Soil Properties of the Five Forest Development Stages

\begin{tabular}{|c|c|c|c|c|c|}
\hline & Regeneration & Initial & Climax & Over-mature & Decay \\
\hline Canopy closure $(\%)$ & $82 \pm 1.4 \mathrm{ab}$ & $91 \pm 0.8 \mathrm{a}$ & $90 \pm 0.3 a$ & $85 \pm 0.6 a$ & $74 \pm 1.0 \mathrm{~b}$ \\
\hline \multicolumn{6}{|l|}{ Living trees ${ }^{1}$} \\
\hline Stem density $\left(N \mathrm{ha}^{-1}\right)$ & $40 \pm 40 a$ & $960 \pm 289 b$ & $480 \pm 66 \mathrm{ab}$ & $380 \pm 37 a b$ & - \\
\hline Basal area $\left(\mathrm{m}^{2} \mathrm{ha}^{-1}\right)$ & $0.2 \pm 0.2 \mathrm{a}$ & $14.0 \pm 4.8 \mathrm{a}$ & $70.5 \pm 5.4 b$ & $72.6 \pm 7.8 b$ & - \\
\hline Mean tree height $(\mathrm{m})$ & 3.2 & $6.6 \pm 0.2 \mathrm{a}$ & $22.5 \pm 1.4 b$ & $22.3 \pm 0.8 b$ & - \\
\hline Mean dbh $(\mathrm{cm})$ & 7.6 & $12.4 \pm 0.6 \mathrm{a}$ & $43.2 \pm 3.3 b$ & $48.6 \pm 1.3 b$ & - \\
\hline \multicolumn{6}{|l|}{ Seedlings } \\
\hline Seedling density $\left(N \mathrm{ha}^{-1}\right)$ & $10240 \pm 1031 b$ & $2640 \pm 337 a$ & $1380 \pm 530 a$ & $3120 \pm 1203 a$ & $2160 \pm 717 a$ \\
\hline Mean seedling height $(\mathrm{cm})$ & $70 \pm 12 \mathrm{ab}$ & $124 \pm 37 a$ & $64 \pm 34 \mathrm{ab}$ & $38 \pm 5.7 b$ & $34 \pm 2.3 b$ \\
\hline Mean root collar diameter $(\mathrm{cm})$ & $1.3 \pm 0.2 \mathrm{a}$ & $2.2 \pm 0.5 a$ & $1.3 \pm 0.6 b$ & $1.0 \pm 0.1 \mathrm{a}$ & $0.9 \pm 0.1 a$ \\
\hline \multicolumn{6}{|l|}{ Standing deadwood and stumps } \\
\hline Stem density ${ }^{1)}\left(N\right.$ ha $\left.^{-1}\right)$ & $425 \pm 170 \mathrm{ab}$ & $200 \pm 91 \mathrm{ab}$ & $125 \pm 25 b$ & $320 \pm 58 a b$ & $460 \pm 60 a$ \\
\hline Basal area $\left(\mathrm{m}^{2} \mathrm{ha}^{-1}\right)$ & $49.3 \pm 14.6 \mathrm{a}$ & $32.5 \pm 13 a b$ & $5.1 \pm 2.2 b$ & $24.4 \pm 6.5 \mathrm{ab}$ & $96.7 \pm 7.9 c$ \\
\hline Mean snag height $(\mathrm{m})$ & $2.3 \pm 0.9 a$ & $1.2 \pm 0.4 a$ & $1.8 \pm 1.1 \mathrm{a}$ & $3.3 \pm 0.7 a$ & $8.9 \pm 2.4 b$ \\
\hline Mean dbh $(\mathrm{cm})$ & $31.4 \pm 7.1 \mathrm{ab}$ & $24.9 \pm 7.3 \mathrm{ab}$ & $13.9 \pm 4.1 \mathrm{a}$ & $21.7 \pm 3.1 \mathrm{ab}$ & $44.6 \pm 6.5 b$ \\
\hline \multicolumn{6}{|l|}{ Soil properties } \\
\hline $\mathrm{C} / \mathrm{N}$ ratio & $19.5 \pm 0.7 a$ & $20.2 \pm 1.7 a$ & $21.6 \pm 2.1 \mathrm{a}$ & $19.4 \pm 1.1 \mathrm{a}$ & $19.0 \pm 1.0 \mathrm{a}$ \\
\hline Soil C concentration $(\%)$ & $23.1 \pm 5.4 a$ & $31.8 \pm 5.9 a$ & $26.5 \pm 5.1 a$ & $22.9 \pm 5.7 a$ & $27.6 \pm 5.4 a$ \\
\hline Bulk density $\left(\mathrm{g} \mathrm{cm}^{-2}\right)$ & $0.8 \pm 0.13 a$ & $0.6 \pm 0.03 a$ & $0.8 \pm 0.07 a$ & $0.7 \pm 0.06 a$ & $0.7 \pm 0.06 a$ \\
\hline Base saturation (\%) & $39.2 \pm 7.0 \mathrm{a}$ & $41.6 \pm 8.0 \mathrm{a}$ & $38.6 \pm 7.3 a$ & $41.8 \pm 5.5 a$ & $35.3 \pm 3.9 a$ \\
\hline $\mathrm{pH}_{\mathrm{H} 2 \mathrm{O}}$ & $3.8 \pm 0.06 a$ & $3.6 \pm 0.24 a$ & $3.8 \pm 0.03 a$ & $3.6 \pm 0.11 \mathrm{a}$ & $3.7 \pm 0.06 a$ \\
\hline $\mathrm{pH}_{\mathrm{KCl}}$ & $3.4 \pm 0.07 a$ & $3.3 \pm 0.22 \mathrm{a}$ & $3.2 \pm 0.06 a$ & $3.1 \pm 0.13 a$ & $3.3 \pm 0.08 a$ \\
\hline
\end{tabular}

$n=5$. Given are means and standard errors. Different letters indicate significant differences between the forest development stages. 
Table 4. Biomass and Carbon Pools of the Different Above- and Belowground Compartments

\begin{tabular}{|c|c|c|c|c|c|}
\hline & Regeneration & Initial & Climax & Over-mature & Decay \\
\hline \multicolumn{6}{|l|}{ Living trees } \\
\hline Biomass ( $\left.\mathrm{Mg} \mathrm{ha}^{-1}\right)$ & $0.33 \pm 0.33 a$ & $42 \pm 16 a$ & $339 \pm 30 b$ & $328 \pm 42 b$ & - \\
\hline Carbon pool $\left(\mathrm{Mg} \mathrm{C} \mathrm{ha}^{-1}\right)$ & $0.17 \pm 0.17 \mathrm{a}$ & $21 \pm 7.8 \mathrm{a}$ & $171 \pm 15 b$ & $165 \pm 21 b$ & - \\
\hline \multicolumn{6}{|l|}{ Seedling biomass } \\
\hline Biomass ( $\left.\mathrm{Mg} \mathrm{ha}^{-1}\right)$ & $0.14 \pm 0.02 \mathrm{a}$ & $0.06 \pm 0.01 b$ & $0.01 \pm 0.01 \mathrm{c}$ & $0.02 \pm 0.01 c$ & $0.02 \pm 0.01 \mathrm{c}$ \\
\hline Carbon pool $\left(\mathrm{Mg} \mathrm{C} \mathrm{ha}^{-1}\right)$ & $0.07 \pm 0.01 \mathrm{a}$ & $0.03 \pm 0.01 b$ & $0.01 \pm 0.00 c$ & $0.01 \pm 0.00 \mathrm{c}$ & $0.01 \pm 0.00 \mathrm{c}$ \\
\hline \multicolumn{6}{|l|}{ Standing deadwood } \\
\hline Mass $\left(\mathrm{Mg} \mathrm{ha}^{-1}\right)$ & $55 \pm 34 a$ & $17 \pm 10 \mathrm{a}$ & $4.0 \pm 2.8 \mathrm{a}$ & $57 \pm 30 a$ & $388 \pm 132 b$ \\
\hline Carbon pool $\left(\mathrm{Mg} \mathrm{C} \mathrm{ha}^{-1}\right)$ & $28 \pm 17 a$ & $8.6 \pm 5.0 \mathrm{a}$ & $2.0 \pm 1.4 \mathrm{a}$ & $29 \pm 15 a$ & $195 \pm 66 b$ \\
\hline Decay class & $5.4 \pm 0.9 a$ & $4.6 \pm 1.2 \mathrm{a}$ & $5.1 \pm 1.1 \mathrm{a}$ & $3.2 \pm 0.4 a$ & $3.6 \pm 0.8 \mathrm{a}$ \\
\hline \multicolumn{6}{|l|}{ Lying deadwood } \\
\hline Mass $\left(\mathrm{Mg} \mathrm{ha}^{-1}\right)$ & $28 \pm 8.9 a$ & $23 \pm 9.2 \mathrm{a}$ & $19 \pm 5.5 a$ & $41 \pm 17 a$ & $15 \pm 6.1 \mathrm{a}$ \\
\hline Carbon pool $\left(\mathrm{Mg} \mathrm{C} \mathrm{ha}^{-1}\right)$ & $14 \pm 4.5 \mathrm{a}$ & $11 \pm 4.6 \mathrm{a}$ & $9.6 \pm 2.8 \mathrm{a}$ & $20 \pm 8.6 a$ & $7.7 \pm 3.1 \mathrm{a}$ \\
\hline Decay class & $4.9 \pm 0.3 a$ & $4.7 \pm 0.4 a$ & $5.0 \pm 0.3 a$ & $4.9 \pm 0.5 a$ & $4.2 \pm 0.4 a$ \\
\hline \multicolumn{6}{|l|}{ Ecosystem C pool } \\
\hline Aboveground C pool $\left(\mathrm{Mg} \mathrm{C} \mathrm{ha}^{-1}\right)$ & $42 \pm 18 \mathrm{a}$ & $41 \pm 15 a$ & $183 \pm 16 \mathrm{ab}$ & $214 \pm 34 b$ & $203 \pm 67 b$ \\
\hline SOC pool $(0-60 \mathrm{~cm})\left(\mathrm{Mg} \mathrm{C} \mathrm{ha}^{-1}\right)$ & $241 \pm 37 a$ & $223 \pm 18 a$ & $276 \pm 44 \mathrm{a}$ & $265 \pm 19 a$ & $221 \pm 16 a$ \\
\hline Total & $291 \pm 21 a b$ & $252 \pm 28 a$ & $464 \pm 35 b c$ & $453 \pm 19 b c$ & $485 \pm 79 c$ \\
\hline
\end{tabular}

Decay classes for deadwood after Holeksa (2001). Given are means \pm standard errors, $N=5$ plots per development stage. Different letters indicate significant differences between the forest development stages.

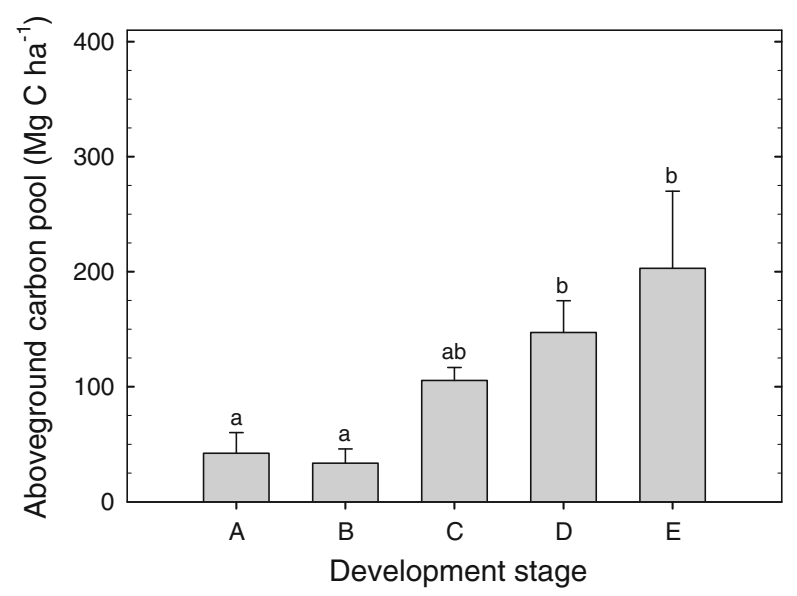

Figure 1. Total aboveground (living trees, tree regeneration, deadwood) carbon stocks $\left(\mathrm{Mg} \mathrm{ha}^{-1}\right)$ in five development stages ( $A$ regeneration, $B$ initial, $C$ climax, $D$ over-mature, $E$ decay stage). Given are means and standard error of $N=5$ plots. Significant differences between the development stages are indicated with lower-case letters.

\section{Soil Carbon Stocks}

The soil physical and chemical properties showed no significant differences between the five development stages for all analyzed parameters (Table 3). The soil texture of all plots was similar and dominated by sand and silt (sand 52\%, silt
$36 \%$, clay $12 \%$; data not shown). The mean soil profile depth to the bedrock surface was $54 \mathrm{~cm}$. The soil carbon stocks did not differ between the development stages in any soil depth (Figure 2). All topsoils had high concentrations of SOC due to a tendency to the formation of shallow Histosol profiles $(40 \% \mathrm{C}$ of the total dry mass at $0-10 \mathrm{~cm}$, $15 \%$ at $10-20 \mathrm{~cm})$. The SOC content decreased to $8.5 \%$ at $20-40 \mathrm{~cm}$ depth and $3 \%$ at $40-60 \mathrm{~cm}$. The highest carbon stocks (ca. $140 \mathrm{Mg} \mathrm{ha}^{-1}$ ) were found in the upper soil $(0-20 \mathrm{~cm})$; the stores were about $70 \mathrm{Mg} \mathrm{Cha}^{-1}$ at $20-40 \mathrm{~cm}$ and $40 \mathrm{Mg} \mathrm{C} \mathrm{ha}^{-1}$ at $40-60 \mathrm{~cm}$. This adds up to profile totals of around $250 \mathrm{Mg} \mathrm{C} \mathrm{ha}^{-1}$.

\section{Ecosystem Carbon Stocks}

On the landscape level, the over-mature (D) and decay (E) stages were over-represented in the studied forest; together they occupied approximately $66 \%$ of the total area (Table 5). These two stages had very high total ecosystem carbon stocks between 450 and $485 \mathrm{Mg} \mathrm{C} \mathrm{ha}^{-1}$ that sum up to $90 \mathrm{Gg} \mathrm{C}$ in the whole area of $300 \mathrm{ha}$, whereas the regeneration (A) and initial (B) stages together contributed only with around $15 \mathrm{Gg} C$ to the total carbon stock of the studied forest (Tables 4,5 ). The mean weighted total carbon pool per hectare of the study area calculated from Table 5 is $422 \mathrm{Mg} \mathrm{C} \mathrm{ha}^{-1}$, 


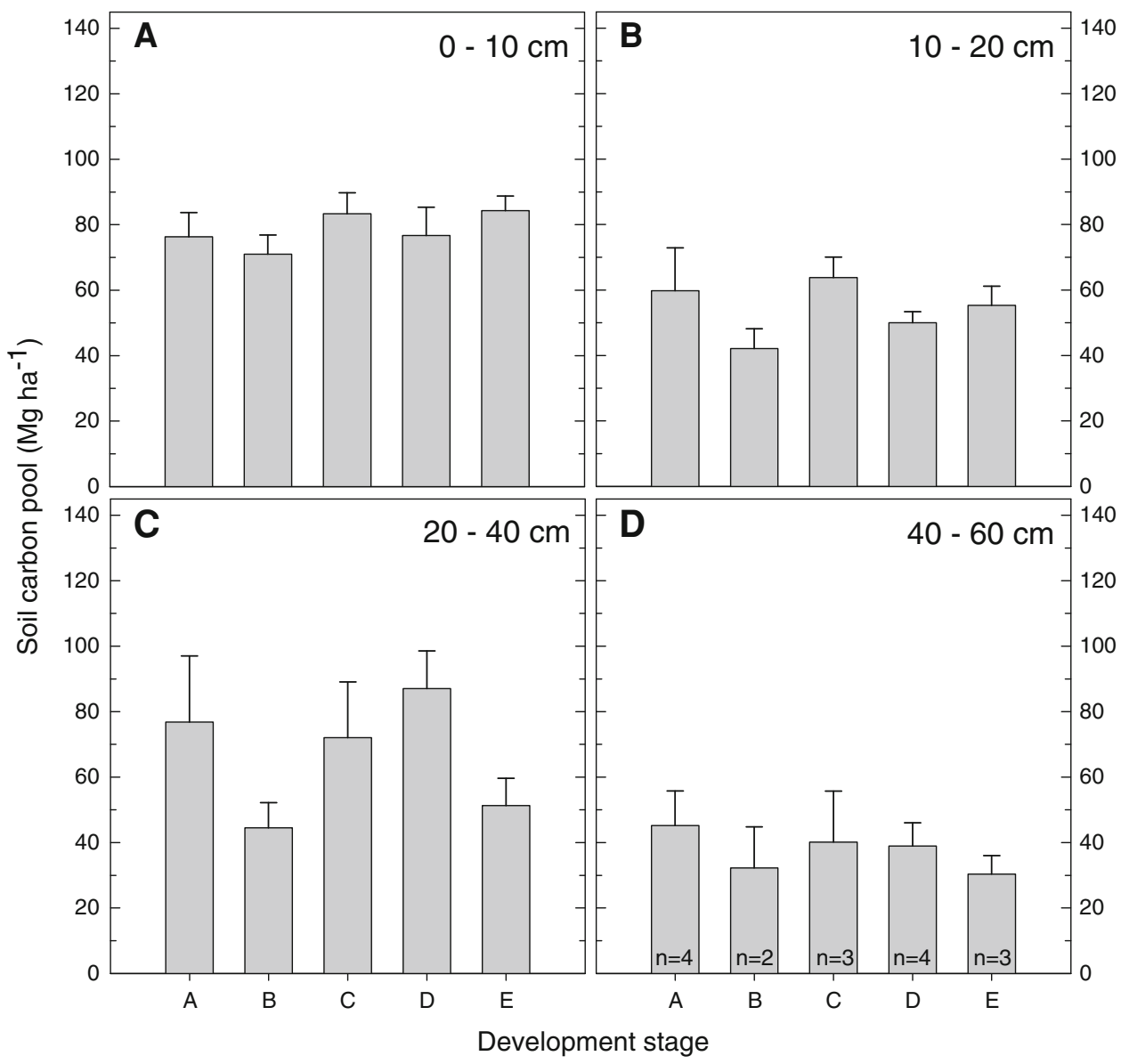

Figure 2. Soil carbon stocks $\left(\mathrm{Mg} \mathrm{ha}^{-1}\right)$ in different soil layers (0-10, $10-20,20-40,40-60 \mathrm{~cm})$ in the five development stages ( $A$ regeneration, $B$ initial, $C$ climax, $D$ overmature, $E$ decay stage). Given are means and standard error of $N=5$ plots. For the $40-60 \mathrm{~cm}$ layer $n$ is indicated in each bar (reduced replicate number due to high bedrock surface).

Table 5. Carbon Pools and Distribution of the Five Different Development Stages on the Landscape Level

\begin{tabular}{|c|c|c|c|c|c|}
\hline & Regeneration & Initial & Climax & Over-mature & Decay \\
\hline Frequency of each development stage (\%) & 8.4 & 10.3 & 14.9 & 39.1 & 27.3 \\
\hline Area of each development stage (ha) & 25 & 31 & 45 & 117 & 82 \\
\hline Landscape aboveground C pool ( $\left.\mathrm{Mg} \mathrm{C} 300 \mathrm{ha}^{-1}\right)$ & 1,066 & 1,276 & 8,158 & 25,144 & 16,627 \\
\hline Landscape SOC pool (Mg C $\left.300 \mathrm{ha}^{-1}\right)$ & 6,068 & 6,895 & 12,319 & 31,097 & 18,105 \\
\hline Total landscape C pool (Mg C $\left.300 \mathrm{ha}^{-1}\right)$ & 7,134 & 8,170 & 20,477 & 56,242 & 34,732 \\
\hline
\end{tabular}

and thus close to the ecosystem carbon pool of the over-mature stage (Table 4).

\section{Discussion}

In this old-growth mountain spruce forest, the ecosystem carbon pool varied nearly by a factor of two across the different stand development stages, increasing from $250-290 \mathrm{Mg} \mathrm{C} \mathrm{ha}^{-1}$ in the regeneration and initial stages to $450-485 \mathrm{Mg} \mathrm{C} \mathrm{ha}^{-1}$ in the over-mature and decay stages. Thus, our measurements indicate that the forest $\mathrm{C}$ pool experiences a cyclic variation with an amplitude of around $200 \mathrm{MgC} \mathrm{ha}^{-1}$ in the approximately 300 year-long forest dynamics cycle (Stöcker 1997) of this mono-specific coniferous forest. This variation is nearly entirely caused by tree age-dependent alteration in the aboveground live and dead biomass fractions, whereas the SOC pool showed no significant trend across the five development stages. The very high biomass and ecosystem C pools in the over-mature and decay stages are primarily the consequence of the low decay rate in the cold and wet environment of the studied mountain forest close to the alpine timberline with 5 months snow cover and a mean annual temperature close 
to $3^{\circ} \mathrm{C}$ (Glässer 1994). With the death of all spruce trees until the end of the over-mature stage, 170$190 \mathrm{Mg} \mathrm{C} \mathrm{ha}{ }^{-1}$ are transferred to the fraction of standing deadwood and are fully decomposed not before the end of the regeneration stage in the next forest generation. In a subalpine spruce forest of the Carpathians with a similar climate as in our study area, spruce snags and logs had a mean residence time of 47-63 years (volume-based calculation) or 71-113 years (log number-based calculation) (Holeksa and others 2008). The continuous persistence of deadwood across subsequent tree generations is a characteristic feature of temperate high-elevation and boreal (high-latitude) forests and distinguishes them from forests in warmer climates at lower elevation and latitude (Zielonka 2006; Vandekerkhove and others 2009).

The stable SOC pool during the roughly 300 years of a spruce forest dynamics cycle agrees with the results obtained from other studies in coniferous forests (for example, Peichl and Arain 2006; Bradford and others 2008). This contrasts with the review of Pregitzer and Euskirchen (2004), who found the highest SOC stocks in the oldest stand age classes along chronosequences in the earth's main forest biomes; in the boreal forest, these authors assumed the SOC pools to be twice as high in mature than young stands. However, Gleixner and others (2009) re-analyzed the tree age-SOC relationship in temperate coniferous forests with a data set solely consisting of studies with chronosequence data and found no increase, but rather an insignificant trend for a SOC decrease, with increasing age. We explain the lack of significant changes in the SOC pool during the forest development cycle in our study with the low temperature and the absence of stages with high radiation transmission to the forest floor as they may result from stand-level disturbance. In the studied forest, even the decay and regeneration stages reached a canopy closure of 74 and $80 \%$, respectively, partly due to the high density of standing deadwood. Therefore, development stages with warmer soil and reduced (more favorable) soil moisture conditions, which could promote decomposer activity, are lacking in this cold and moist environment. The positive effect of the generally low temperature on the size of the SOC pool is well demonstrated by the 2-3 fold larger soil C pool in this high-elevation old-growth spruce forest $\left(220-275 \mathrm{Mg} \mathrm{C}^{-1}\right.$ at $\left.0-60 \mathrm{~cm}\right)$ as compared to managed lowland spruce forests in Germany (ca. 50-70 Mg C ha ${ }^{-1}$ at $0-30 \mathrm{~cm}$, Oehmichen and others 2011; 80-100 Mg C ha ${ }^{-1}$ at $0-90 \mathrm{~cm}$; Wördehoff and others 2012). Another reason for the high SOC pools is most likely the long forest continuity at Mt. Brocken which is not found in most lowland spruce stands. Centuries of SOC accumulation in a climate with a tendency for carpet bog formation may well result in soil C stocks greater than $200 \mathrm{Mg} \mathrm{C} \mathrm{ha}^{-1}$.

Our estimates of the aboveground live biomass pool are much higher in their maximum at the climax stage $\left(>170 \mathrm{Mg} \mathrm{C} \mathrm{ha}{ }^{-1}\right)$ than averages given for boreal coniferous forests (for example, Gower and others 1994; Pregitzer and Euskirchen 2004; Bradford and others 2008; Keith and others 2009). Even when the landscape-scale mean of the Mt. Brocken forest is considered (c. $92 \mathrm{Mg} \mathrm{C} \mathrm{ha}^{-1}$ ), this figure is still considerably higher than the mean of $73 \mathrm{Mg}$ dry mass (c. $36 \mathrm{Mg} \mathrm{C} \mathrm{ha}^{-1}$ ) given by Gower and others (1994) for 58 boreal pine stands or the average of $61 \mathrm{Mg}$ dry mass $\mathrm{ha}^{-1}$ for Eurasian and American boreal forests reported by Jarvis and others (2001). This difference is probably mainly attributable to the higher summer temperatures and longer growing season in the temperate Harz Mountains than in most parts of the boreal zone. In addition, stand-replacing fires, which are characteristic for many parts of the boreal forest zone (Bergeron and Harper 2009), are virtually absent from the Mt. Brocken spruce forests. Consequently, the basal area is high with greater than $70 \mathrm{~m}^{2} \mathrm{ha}^{-1}$ in the climax and over-mature stages of this forest, associated with a continuing accumulation of live biomass in the aging trees (see Schulze and others 2009). In this forest, rare standlevel disturbance is mostly a consequence of insect calamities and windthrow. Another factor that needs consideration is nitrogen. In Europe and parts of eastern North America, decades of high $\mathrm{N}$ deposition are thought to be a main cause of large increases in forest productivity and biomass stocks as were observed in the past 50 years (Nabuurs and others 2003; Boisvenue and Running 2006). Ciais and others (2008) estimated that the biomass carbon stocks in European forests have increased by a factor of 1.8 during this period. This must also have influenced the high-elevation spruce forests on Mt. Brocken. In fact, dendrochronological records showed a pronounced increase in the radial stem growth of spruce in the studied forest during the last 10-15 years (Hauck and others 2012a), which should have increased the biomass stocks. This suggests that the average tree biomass may not be in a long-term equilibrium in this old-growth forest, independent from biomass fluctuations due to stand dynamics. Nevertheless, the total (live and dead) aboveground biomass carbon pools of the late forest development stages (ca. 200-215 $\mathrm{Mg} \mathrm{C} \mathrm{ha}^{-1}$ ) 
are already high in comparison to Central European lowland spruce plantations despite the cooler climate. Typical biomass figures of such managed stands are in the range of $110-140 \mathrm{Mg} \mathrm{C} \mathrm{ha}^{-1}$ at maturity (70-140 years old; Ellenberg and Leuschner 2010; Oehmichen and others 2011) which is roughly $40 \%$ less than is present in the overmature and decay stages of the natural mountain spruce forest. Finally, it must be kept in mind that the allometric equations used for calculating aboveground biomass were established in managed age-class spruce forests and not derived from natural forests; this may have introduced a certain bias in the wood mass data of our study.

When assessing the value of old-growth forests with high carbon density in biomass and soil with respect to their potential of reducing $\mathrm{CO}_{2}$ emissions, it has to be kept in mind that managed forests produce commercial wood for products that can lower carbon emissions from fossil fuels when they are substituting other products that are produced with more energy input. For example, Rüter (2011) and Rock and Bolte (2011) calculated for the German forest sector that $1 \mathrm{Mg}$ of carbon in wood removed from the forest may replace on average $1.1-1.35 \mathrm{Mg}$ of carbon emissions from fossil fuel sources. If the wood is left to decay in the forest, net emissions of $\mathrm{C}$ are the carbon stored in the respective piece of wood plus these forgone replacements. Thus, high wood biomass stores per se are not a good argument for protecting oldgrowth forests. However, the montane spruce forest on Mt. Brocken stores (as an average across all five stages) roughly $35 \%$ of the C in AGB and $65 \%$ in the soil. Harvest most likely will considerably reduce the soil $\mathrm{C}$ storage for several decades and this loss is probably as large as, or greater than, the $\mathrm{CO}_{2}$ emission reduction achieved when harvested wood substitutes other products with higher associated $\mathrm{CO}_{2}$ emission. This underscores the positive impact of this mountain spruce forest on the regional carbon budget.

Our study demonstrates the high significance of patches with over-mature and decaying trees for carbon storage in Central European natural coniferous forests, a result which is probably transferable to other mountain forest ecosystems in the temperate zone. The conservation value of old and decaying trees for protecting specialized taxa of forest biodiversity is already well established (Ódor and others 2006; Hauck and others 2012b; Dittrich and others 2012). The present study quantifies the important role of over-mature and decaying forest development stages for ecosystem carbon storage that has rarely been examined in a landscape-scale context. Our results support the view that the decay stage at the end of a forest dynamics cycle with the breakdown of the stand does not decrease, but rather increase, ecosystem carbon storage, because the SOC store remains high and the biomass reduction occurs only after a considerable lag phase in the regeneration and initial phases of the next forest generation. This may be a characteristic of natural forests in cool and moist climates where large forest fires are rare and biomass reduction after break-down or disturbance occurs more gradually. The findings should be an additional incentive to protect the over-mature and decay stages of mountain forests with high SOC stores.

\section{ACKNOWLEDGMENTS}

The study was funded by the Stemmler Foundation, a member of the Stifterverband für die Deutsche Wissenschaft through a grant to $\mathbf{M}$. Hauck and Ch. Leuschner. The grant was approved in the framework of the Stifterverband program 'Biodiversity and Ecology in National Parks (BEN)'. We are grateful to the Harz National Park administration, and to Dr. H.-U. Kison and A. Rommerskirchen in particular, for granting permissions and manifold support of our work.

\section{OPEN ACCESS}

This article is distributed under the terms of the Creative Commons Attribution License which permits any use, distribution, and reproduction in any medium, provided the original author(s) and the source are credited.

\section{REFERENCES}

Bergeron Y, Harper KA. 2009. Old-growth forest in the Canadian boreal: the exception rather than the rule? In: Wirth $\mathrm{C}$, Gleixner G, Heimann M, Eds. Old-growth forests: function, fate, and value. Ecological Studies, vol 207. Berlin: Springer. pp 285-300.

Boisvenue C, Running SW. 2006. Impacts of climate change on natural forest productivity-evidence since the middle of the 20th century. Glob Change Biol 12:862-82.

Bonan GB. 2008. Forests and climate change: forcings, feedbacks, and the climate benefits of forests. Science 320:1444-9.

Bradford JB, Birdsey RA, Joyce LA, Ryan MG. 2008. Tree age, disturbance history, and carbon stocks and fluxes in subalpine Rocky Mountain forests. Glob Change Biol 14:2882-97.

Chatterjee A, Vance GF, Tinker DB. 2009. Carbon pools of managed and unmanaged stands of ponderosa and lodgepole pine forests in Wyoming. Can J For Res 39:1893-900.

Chen HYH. 1997. Interspecific responses of planted seedlings to light availability in interior British Columbia: survival, growth, allometric patterns, and specific leaf area. Can J For Res 27:1383-93. 
Ciais P, Schelhaas MJ, Zaehle S, Piao SL, Cescatti A, Liski J, Luyssaert S, Le-Maire G, Schulze E-D, Bouriaud O, Freibauer A, Valentini R, Nabuurs GJ. 2008. Carbon accumulation in European forests. Nat Geosci 1:425-9.

Černý M. 1990. Biomass of Picea abies L. Karst. in Midwestern Bohemia. Scand J For Res 5:83-95.

Dittrich S, Hauck M, Jacob M, Rommerskirchen A, Leuschner C. 2012. Response of ground vegetation and epiphyte diversity to natural age dynamics in a Central European mountain spruce forest. J Veg Sci. doi:10.1111/j.1654-1103.2012.01490.x.

Dolman A, van der Werf G, van der Molen MK, Ganssen G, Erisman J, Strengers B. 2010. A carbon cycle science update since IPCC AR-4. Ambio 39:402-12.

Ellenberg H, Leuschner C. 2010. Vegetation Mitteleuropas mit den Alpen, 6th ed. Stuttgart: Ulmer. 1333 pp.

Glässer R. 1994. Das Klima des Harzes. Hamburg: Kovač. 341 pp. Glatzel G. 1999. Historic forest use and its possible implications to recently accelerated tree growth in Central Europe. In: Karjalainen T, Spiecker H, Laroussinie O, Eds. Causes and consequences of accelerating tree growth in Europe. EFI proceedings No. 27. European Forest Institute, Joensuu, Finland. pp 77-88.

Gleixner G, Tefs C, Jordan A, Hammer M, Wirth C, Nueske A, Telz A, Schmidt UE, Glatzel S. 2009. Soil carbon accumulation in old-growth forests. Wirth C, Gleixner G, Heimann M, Eds. Old-growth forests: function, fate, and value. Ecological Studies, vol 207. Berlin: Springer. pp 231-266.

Gower ST, Gholz HL, Nakane K, Badwin VC. 1994. Production and allocation patterns of pine forests. Ecol Bull (Copenhagen) 43:115-35.

Hauck M, Zimmermann J, Jacob M, Dulamsuren Ch, Bade C, Ahrends B, Leuschner C. 2012a. Rapid recovery of stem increment in Norway spruce at reduced $\mathrm{SO}_{2}$ levels in the Harz Mountains. Germany, Environ Pollut 164:132-41.

Hauck M, de Bruyn U, Leuschner C. 2012b. Dramatic diversity losses in epiphytic lichens in temperate broad-leaved forests during the last 150 years. Biol Conserv. doi:10.1016/j.biocon.2012.06.015.

Hilmo O, Holien H, Hytteborn H, Ely-Aalstrup H. 2009. Richness of epiphytic lichens in differently aged Picea abies plantations situated in the oceanic region of Central Norway. Lichenologist 41:97-108.

Holeksa J. 2001. Coarse woody debris in a Carpathian subalpine spruce forest. Forstwissenschaftliches Centralblatt 120:256-70.

Holeksa J, Zielonka T, Zywiec M. 2008. Modeling the decay of coarse woody debris in a subalpine Norway spruce forest of the West Carpathians, Poland. Can J For Res 38:415-28.

Intergovernmental Panel on Climate Change. 2007. The fourth assessment report climate change 2007: synthesis report. In: Pachauri RK, Reisinger A, Eds. Contribution of Working Groups I, II, and III, Intergovernmental Panel on Climate Change, Geneva. 52 pp.

Jacobs ED. 1871. Der Brocken und sein Gebiet. Erste Hälfte. Zeitschrift des Harz-Vereins für Alterthumskunde 3:1-139.

Jacobs ED. 1878. Brockenfragen. Zeitschrift des Harz-Vereins für Alterthumskunde 1:433-75.

Jarvis PG, Saugier B, Schulze E-D. 2001. Productivity of boreal forests. In: Roy J, Saugier B, Mooney HA, Eds. Terrestrial global productivity. San Diego: Academic Press. p 211-44.

Keith H, Mackey BG, Lindenmayer DB. 2009. Re-evaluation of forest biomass carbon stocks and lessons from the world's most carbon-dense forests. Proc Natl Acad Sci USA 106:11635-40.

Kortzfleisch Av. 2008. Die Kunst der schwarzen Gesellen-Köhlerei im Harz. Papierflieger, Clausthal-Zellerfeld. $349 \mathrm{p}$.

Luyssaert S, Ciais P, Piao SL, Schulze E-D, Jung M, Zaehle S, Schelhaas MJ, Reichstein M, Churkina G, Papale D, Abril G, Beer C, Grace J, Loustau D, Matteucci G, Magnani F, Nabuurs GJ, Verbeeck H, Sulkava M, Van der Werf GR, Janssens IA, members of the Carboeurope-IP Synthesis Team. 2010. The European carbon balance. Part 3: forests. Glob Change Biol 16:1429-50.

Luyssaert S, Schulze E-D, Börner A, Knohl A, Hessemöller D, Law BE, Ciais P, Grace J. 2008. Old-growth forests as global carbon sinks. Nature 455:213-15.

Merganičová K, Merganič J. 2010. Coarse woody debris carbon stocks in natural spruce forests of Babia hora. J For Sci 56:397-405.

Mund M, Profft I, Wutzler T, Schulze E-D, Weber G, Weller E. 2006. Vorbereitungen für eine laufende Fortschreibung der Kohlenstoffvorräte in den Wäldern Thüringens. Thüringer Landesanstalt für Wald, Jagd und Fischerei and Max-PlanckInstitut für Biogeochemie Jena. 136 pp.

Nabuurs GJ, Schelhaas MJ, Mohren G (frits) MJ, Field CB. 2003. Temporal evolution of the European forest sector carbon sink from 1950 to 1999. Glob Change Biol 9:152-60.

Ódor P, Heilmann-Clausen J, Christensen M, Aude E, van Dort KW, Piltaver A, Siller I, Veerkamp MT, Walleyn R, Standovár T, van Hees AFM, Kosec J, Matočec N, Kraigher H, Grebenc T. 2006. Diversity of dead wood inhabiting fungi and bryophytes in semi-natural beech forests in Europe. Biol Conserv 131:5871.

Oehmichen K, Demant B, Dunger K, Grüneberg E, Hennig P, Kroiher F, Neubauer M, Polley H, Riedel T, Rock J, Schwitzgebel F, Stümer W, Wellbrock N, Ziche D, Bolte A. 2011. Inventurstudie 2008 und Treibhausgasinventar Wald. Landbauforschung Sonderheft 343, Johann-Heinrich-vonThünen-Institut; Bundesministerium für Ernährung, Landwirtschaft und Verbraucherschutz, Braunschweig. 164 p.

Peichl M, Arain M. 2006. Above- and belowground ecosystem biomass and carbon pools in an age-sequence of temperate pine plantation forests. Agric For Meteorol 140:51-63.

Pregitzer K, Euskirchen E. 2004. Carbon cycling and storage in world forests: biome patterns related to forest age. Glob Change Biol 10:2052-77.

Rock J. 2007. Suitability of published biomass equations for aspen in Central Europe - results from a case study. Biomass Bioenergy 31:299-307.

Rock J, Bolte A. 2011. Auswirkungen der Waldbewirtschaftung 2002 bis 2008 auf die $\mathrm{CO}_{2}$-Bilanz. Allgemeine Forst-Zeitschrift für Wald- und Forstwirtschaft 15:22-4.

Rüter S. 2011. Welchen Beitrag leisten Holzprodukte zur $\mathrm{CO}_{2}-$ Bilanz? Allgemeine Forst-Zeitschrift für Wald- und Forstwirtschaft 15:15-18.

Ryan MG, Binkley D, Fownes JH. 1997. Age-related decline in forest productivity: pattern and process. In: Begon M, Fitter AH, Eds. Advances in ecological research. San Diego: Academic press. p 213-62.

Schade R. 1926. Der Brocken-Abhandlungen über Geschichte und Natur des Berges. Appelhans and Comp., Braunschweig. $126 \mathrm{p}$. 
Schiegg K. 2000. Effects of dead wood volume and connectivity on saproxylic insect species diversity. Ecoscience 7:290-8.

Schulze ED, Lloyd J, Kelliher FM, Wirth C, Rebmann C, Lühker B, Mund M, Knohl A, Milyukova IM, Schulze W, Ziegler W, Varlagin A, Sogachev AF, Valentini R, Dore S, Grigoriev S, Kolle O, Panfyorov MI, Tchebakova N, Vygodskaya N. 1999. Productivity of forests in the Eurosiberian boreal region and their potential to act as a carbon sink-a synthesis. Glob Change Biol 5:703-22.

Schulze ED, Hessenmoeller D, Knohl A, Luyssaert S, Boerner A, Grace J. 2009. Temperate and boreal old-growth forests: How do their growth dynamics and biodiversity differ from young stands and managed forests? In: Wirth C, Gleixner G, Heimann M, Eds. Old-growth forests: function, fate, and value. Ecological Studies, vol 207. Berlin: Springer. pp 343-66.

Stöcker G. 1997. Struktur und Dynamik der Berg-Fichtenwälder im Hochharz. Berichte der Naturhistorischen Gesellschaft Hannover 139:31-59.
Vandekerkhove K, De Keersmaeker L, Menke N, Meyer P, Verschelde P. 2009. When nature takes over from man: dead wood accumulation in previously managed oak and beech woodlands in North-western and Central Europe. For Ecol Manage 258:425-35.

Wördehoff R, Spellmann H, Evers J, Nagel J, Gaertner U. 2012. Kohlenstoffstudie Forst und Holz Sachsen-Anhalt. Göttingen: Nordwestdeutsche Forstliche Versuchsanstalt. p 108.

Yanai RD, Currie WS, Goodale CL. 2003. Soil carbon dynamics after forest harvest: an ecosystem paradigm reconsidered. Ecosystems 6:197-212.

Zhou G, Liu S, Li Z, Zhang D, Tang X, Zhou C, Yan J, Mo J. 2006. Old-growth forests can accumulate carbon in soils. Science 314:1417.

Zielonka T. 2006. When does dead wood turn into a substrate for spruce replacement? J Veg Sci 17:739-46. 